\title{
Molecular Species Compositions of Triacylglycerols of Subcutaneous Fat, and Their Association with Total Lipid Content of $M$. longissimus thoracis of Fattened Beef Cattle
}

Makoto ITOH, Keizou ARIHARA

and Yo KONDO

School of Veterinary Medicine and Animal Science,

Kitasato University, Towada-shi 034

(Received July 7, 1997)

\begin{abstract}
The compositions of fatty acid and molecular species of triacylglycerol of subcutaneous fat of fattened Japanese Black, Japanese Shorthorn and Holstein steers were determined by gas chromatography. There were significant differences in heptadecanoic acid concentration among three breeds, and in six acid (myristic, myristoleic, palmitic, palmitoleic, anteiso-heptadecanoic and stearic acids) concentrations between two breeds of three breeds. The relationship between palmitic and oleic acid concentrations was negative. The major molecular species of subcutaneous triacylglycerol were myristoyl (M)-palmitoyl (P)-oleoyl (O)-glycerol (MPO), PPO, PPalmitoleoyl (Po)-O-glycerol ([PPoO]), P-stearoyl (S)-O-glycerol (PSO) and POO. POO had the highest concentration in these molecular species of three breeds. Japanese Black had higher concentrations of PSO and SOL than those of Holstein. Relationships between POL and POO, and $\mathrm{PPO}$ and $\mathrm{POO}$ were positive and negative, respectively. In order to analyze the association of total lipid content of $M$. longissimus thoracis and molecular species composition of triacylglycerol, multiple regression analysis was carried out. In the linear multiple regression analysis, the regression equation of Japanese Black had a good multiple correlation coefficient (0.8110). In discriminant analysis of samples separated according to meat quality score of carcass, the percentage of discrimination were $100 \%$ for each group of Japanese Black and Japanese Shorthorn.
\end{abstract}

Anim. Sci. Technol. (Jpn.) 68 (12) : 1118-1126, 1997

Key words : Triacylglycerol, Molecular species, Subcutaneous fat, Beef

The quantity and the chemical composition of depot fat of meat are important factors affecting the organoleptic qualities of meat ${ }^{2,4,8,16,18,20-21)}$. Characteristics of depot fats are affected by many factors including breed ${ }^{22)}$, $\operatorname{sex}^{22)}$, age ${ }^{6)}$, diet ${ }^{7)}$, degree of fatness ${ }^{11)}$ and the others $^{10,19)}$. Depot fat consists mainly of triacylglycerol, therefore, characteristics of triacylglycerol may influence meat qualities in many ways. The analysis of triacylglycerol characteristics of beef has been carricd out by fatty acid compositions mainly, and only a few carbon number distribution of triacylglycerol ${ }^{12-13,15)}$, while there were no reports for compositions of molecular species of triacylglycerol isolated from subcutaneous fat of Japanese beef cattle. Compositions of molecular species of intramuscular triacylglycerol were determined previously ${ }^{5}$. In the present paper, compositions of the fatty acid and molecular species of triacylglycerol of subcutaneous fat of the fattened beef cattle were 


\section{Molecular Species of Subcutaneous Triacylglycerols}

compared, and associations between molecular species compositions of subcutaneous triacylglycerol and total intramuscular lipid content of $M$. longissimus thoracis or meat quality score were analyzed.

\section{Materials and Methods}

Samples for the fatty acid and molecular species determinations were obtained from subcutaneous fat at between the tenth and the eleventh rib of carcasses, stored at $2^{\circ} \mathrm{C}$ for 24 to 30 hours after slaughter, of Japanese Black ( $\mathrm{n}=$ 10), Japanese Shorthorn $(n=10)$ and Holstein steers $(n=30)$. The details of fattening conditions for these steers were unknown. Extraction of total lipid from samples were carried out by the method of Folch et al. . $^{\text {. }}$. The mean values of total lipid contents with standard deviation in $M$. longissimus thoracis were $30.0 \pm$ $8.3 \%$ for Japanese Black, $11.2 \pm 2.2 \%$ for Japanese Shorthorn, and $18.0 \pm 4.8 \%$ for Holstein steers. Fractionation of triacylglycerol from total lipid was carried out by thin layer chromatography using Silica gel $60 \mathrm{H}$ and hexan : diethylether : acetic acid $(80: 30: 1)$ for the development $t^{5}$.

Fatty acid and molecular species compositions of triacylglycerol were determined by gas chromatography described previously ${ }^{5)}$.

In order to evaluate the relation of total lipid concentration in $M$. longissimus thoracis and molecular species composition, the stepwise multiple regression analysis was carried out ${ }^{4}$. In addition to this analysis, the stepwise discriminant analysis was carried out to analyze the ralation of meat quality score of carcass and molecular species composition. The values of $\mathrm{F}_{\text {in }}$ and $\mathrm{F}_{\text {out }}$ of these analyses were 2.0000 and 1.9999 , individually.

\section{Results and Discussion}

Fatty acid and molecular species compositions of triacylglycerol

Fatty acid compositions of subcutaneous triacylglycerol, and sums and ratios of various types of fatty acids are shown in Table 1. Sums of major fatty acid (palmitic acid (C 16 : $0)$, stearic acid (C 18:0) and oleic acid (C 18:1)) concentrations were approximately $80 \%$ for Japanese Black, $85 \%$ for Japanese Shorthorn and $80 \%$ for Holstein. Significant difference $(\mathrm{P}<0.01)$ among three breeds was found for heptadecanoic (C $17: 0)$ acid concentration, and there were significant differences $(\mathrm{P}<0.01)$ between two of three breeds for myristic (C 14:0), myristoleic (C14:1), palmitic (C16:0), palmitoleic (C $16: 1)$, anteiso-heptadecanoic (a-C 17 : $0)$ and stearic $(\mathrm{C} 18: 0)$ acid concentrations. Sums of saturated fatty acids (SFA) of Japanese Black and Holstein steers were lower levels than that of Japanese Shorthorn, while sums of mono-unsaturated fatty acids (MUFA) and unsaturated fatty acids (UFA) of thesc two breeds were higher than that of Japanese Shorthorn. The ratios of $\mathrm{O} / \mathrm{S}$ and $\mathrm{Po} / \mathrm{S}$ for Japanese Shorthorn were lower than those of Japanese Black and Holstein.

The relationship between oleic acid (C $18: 1)$ and palmitic acid (C16:0) concentrations of subcutaneous triacylglycerol of three breeds is shown in Fig. 1. There were negative relationships between $\mathrm{C} 18: 1$ and $\mathrm{C} 16: 0$ in subcutaneous triacylglycerols of three breeds. Leat ${ }^{\text {T) }}$ showed that the percentage of $\mathrm{C} 18: 0$ in subcutaneous fat of barley-fed Angus and Friesian decreased with age, and was replaced by octadecenoic acid (C18:1) and hexadecenoic acid (C16:1) in the rearing period. These findings suggested that the relationships between $\mathrm{C} 18: 0$ and $\mathrm{C} 18: 1$ or $\mathrm{C} 16: 1$ were negative. In the present study, the negative relationships between $\mathrm{C} 18: 0$ and $\mathrm{C} 16: 1$ was observed clearly for Japanese Black and Japanese Shorthorn, but not for Holstein. Relationships between $\mathrm{C} 18: 0$ and $\mathrm{C} 18: 1$ were not significant for the three breeds. In addition, there was the negative relationship between $C 16: 0$ and $C 18: 1$. Fatty acids having eighteen carbon atoms are formed from $\mathrm{C} 16: 0$ by the fatty acid elongation system. After then, 
Table 1. Fatty acid compositions of the subcutaneous triacylglycerols of Japanese Black, Japanese Shorthorn and Holstein steers

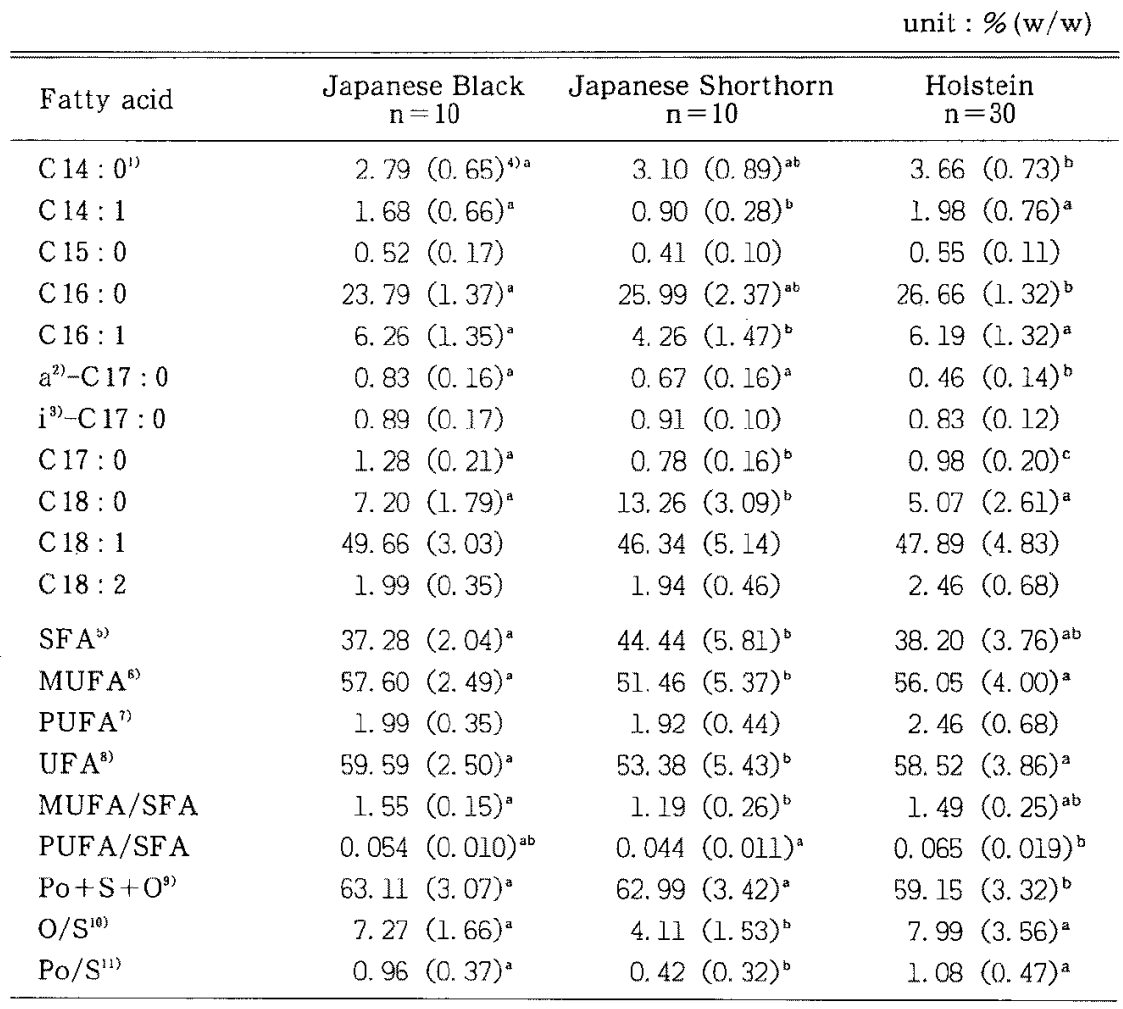

${ }^{1)}$ Chain-length: Number of double bonds ${ }^{2)}$ anteiso ${ }^{3)}$ iso ${ }^{47}$ mean value with standard deviation in bracket ${ }^{5)}$ saturated fatty acid $(\mathrm{C} 14: 0+\mathrm{C} 15: 0+\mathrm{C} 16: 0+a-$ $\mathrm{C} 17: 0+\mathrm{i}-\mathrm{C} 17: 0+\mathrm{C} 17: 0+\mathrm{C} 18: 0)^{6}$ mono-unsaturated fatty acid $(\mathrm{C} 14: 1+\mathrm{C} 16$ : $1+\mathrm{C} 18: 1)^{73}$ poly-unsaturated fatty acid $(\mathrm{C} 18: 2){ }^{83}$ unsaturated fatty acid (MUFA + PUFA) ${ }^{9)} \mathrm{C} 16: 1+\mathrm{C} 18: 0+\mathrm{C} 18: 1{ }^{10} \mathrm{C} 18: 1 / \mathrm{C} 18: 0{ }^{11} \mathrm{C} 16: 1 / \mathrm{C} 18: 0$ $a, b, c$ : Means in the same row with different superscript letters are significantly different $(\mathrm{P}<0.01)$.

C 18: 1 is formed from $\mathrm{C} 18: 0$ by the action of fatty acyl-CoA desaturase. Present relationships may suggest that $\mathrm{C} 18: 1$ may be produced by the systems, described above, from $\mathrm{C}$ $16: 0$ during fatty acid synthesis. C16:1 and C 18: 0 for Japanese Black and Japanese Shorthorn are synthesized competitively from $\mathrm{C} 16$ : 0 .

Molecular species compositions of subcutaneous triacylglycerols of Japanese Black, Japanese Shorthorn and Holstein steers are shown in Table 2. Only molecular species present at $>1 \%$ of the total molecular species of the over twenty five species observed are shown. The major molecular species were myristoyl (M)palmitoyl (P)-oleoyl (O)-glycerol ([MPO]), PPO, $\mathrm{P}$-palmitoleoyl (Po)-O-glycerol (PPoO), Pstearoyl (S)-O-glycerol (PSO) and POO. POO had the highest concentration in the molecular species of the three breeds. Japanese Black had higher concentrations of PSO and SOL than those of Holstein, while Holstein had higher concentration of [PoPoPo], P-hexadecanoyl (H)-L-glycerol ([PHL]) and POL than those of Japanese Black. Concentrations of some molecular species of Japanese Shorthorn were medium values between the other breeds. Tsuneishi et al. ${ }^{15)}$ found that $\mathrm{C} 52$ having two 
Molecular Species of Subcutaneous Triacylglycerols
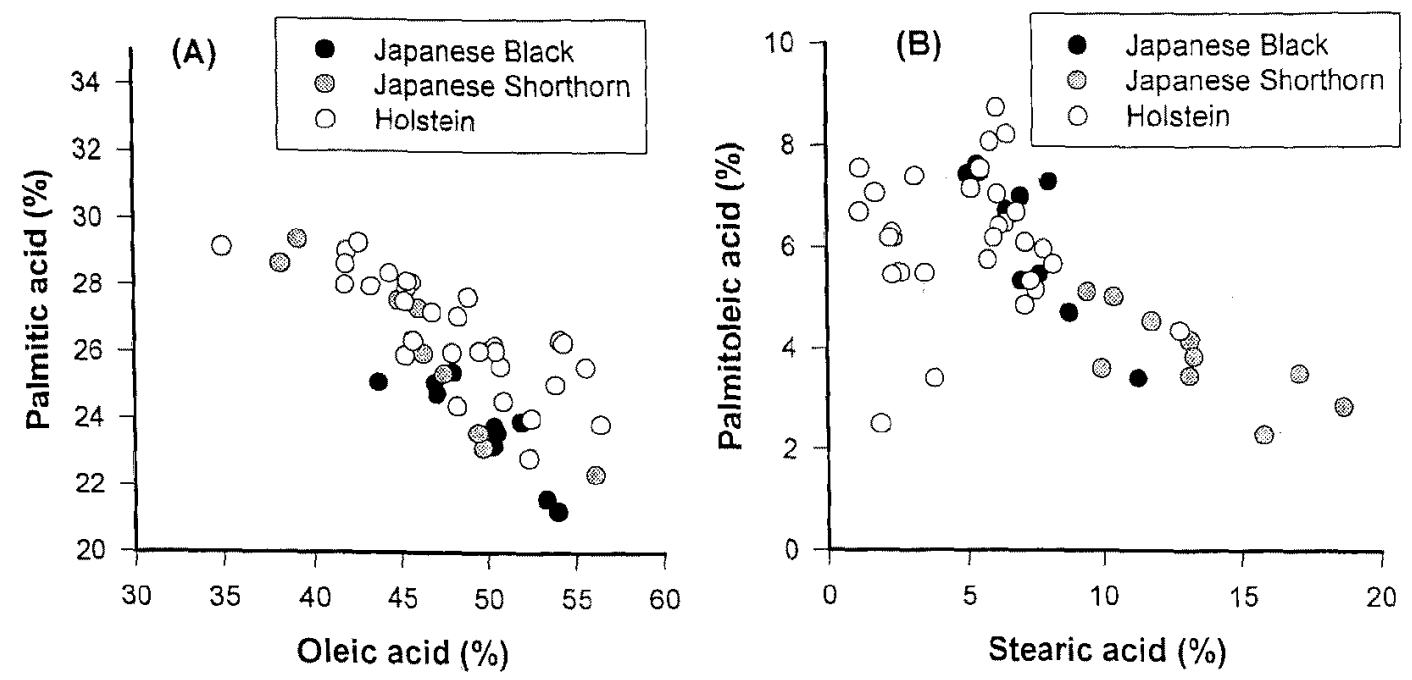

Fig. 1. Relationships between oleic acid and palmitic acic (A), and stearic acid and palmitoleic acid (B) concentrations of the subcutaneous triacylglycerols of Japanese Black, Japanese Shorthorn and Holstein steers.

Table 2. Molecular species compositions of subcutaneous triacylglycerols of Japanese Black, Japanese Shorthorn and Holstein steers

\begin{tabular}{|c|c|c|c|}
\hline Species & $\begin{array}{c}\text { Japanese Black } \\
n=10\end{array}$ & $\begin{array}{c}\text { Japanese Shorthorn } \\
n=10\end{array}$ & $\begin{array}{l}\text { Holstein } \\
n=30\end{array}$ \\
\hline $\mathrm{MMP}^{11}$ & $2.83(1.26)^{3)}$ & $2.16(0.83)$ & $1.63(0.93)$ \\
\hline$[\mathrm{MPPo}]^{2)}$ & $2.40(1.14)$ & $2.65(0.86)$ & $2.91(1.36)$ \\
\hline [MPS] & $4.09(2.22)$ & 3.21 (I.63) & $3.86(1.44)$ \\
\hline [MPO] & $8.36(3.82)$ & $8.49(2.50)$ & $9.02(2.52)$ \\
\hline [PoPoPo] & $2.93(1.65)^{x}$ & $4.84(1.24)^{b}$ & $5.12(1.42)^{\mathrm{b}}$ \\
\hline MSS & $3.36(1.34)$ & $2.76(1.43)$ & $2.43(0.79)$ \\
\hline PPO & 14.83 (3. 15$)$ & 13. $12(1.74)$ & $15.23(1.52)$ \\
\hline$[\mathrm{PPoO}]$ & $8.51(2.29)$ & $10.67(2.83)$ & $13.00(1.59)$ \\
\hline$[\mathrm{PHL}]$ & $1.30(0.54)^{\mathrm{a}}$ & $1.85(0.50)^{\mathrm{a}}$ & $2.49(0.42)^{\mathrm{b}}$ \\
\hline PSO & $12.22(4.54)^{\mathrm{a}}$ & $9.88(5.14)^{\mathrm{ab}}$ & $7.49(2.39)^{\mathrm{b}}$ \\
\hline POO & $25.75(5.32)$ & $25.70(4.75)$ & $24.37(4.61)$ \\
\hline POL & $2.80(1.02)^{\mathrm{a}}$ & $3.31(1.03)^{a b}$ & $4.65(1.06)^{\mathrm{b}}$ \\
\hline SOO & $2.46(1.60)^{\mathrm{a}}$ & $1.99(0.72)^{8}$ & $<0.5^{\mathrm{b}}$ \\
\hline SOL & $5.24(3.02)^{\mathrm{a}}$ & 4. $66(1.33)^{\mathrm{a}}$ & $2.92(1.72)^{\mathrm{b}}$ \\
\hline OOO & $3.00(1.79)$ & $3.53(1.23)$ & $3.23(1.80)$ \\
\hline
\end{tabular}

1) $\mathrm{M}:$ myristoyl, $\mathrm{P}$ : palmitoyl, Po : palmitoleoyl, $\mathrm{H}$ : heptadecanoyl, $\mathrm{S}$ : stearoyl, $\mathrm{O}$ : oleoyl, L: linoleoyl ${ }^{2)}$ presumed species ${ }^{3)}$ mean value with standard deviation in bracket

a.b: Means in the same row with different superscript letters are significantly different $(\mathrm{P}<0.01)$.

(Only molecular species present at $>1 \%$ of total molecular species for one breed are shown.) 
double bonds was the most predominant, and $\mathrm{C}$ 50 s having one double bond and two double bonds were higher than other molecules in triacylglycerol of subcutaneous fat of beef cattle. POO (C 52) having 52 of total carbon number in the acyl groups, has two double bonds, and $\mathrm{PPO}$ (C 50) and [PPoO] (C 50) have one and two double bonds in acyl groups, respectively. The concentration of these molecular species in the present study agreed with the results of Tsuneishi et al. ${ }^{15)}$.

Relationships between POO and PPO, and $\mathrm{POO}$ and POL concentrations in subcutaneous triacylglycerols of the three breeds are shown in Fig. 2. There were negative relationships ( $\mathrm{p}$ $<0.01$ ) between POO and PPO of each breed, and positive relationships $(\mathrm{P}<0.01)$ between POO and POL of each breed. There were no significant slopes among linear regressions for the three breeds from results of the analysis of covariance, while there were significant differences $(\mathrm{P}<0.05)$ of center positions of data and intercepts of regressions between Japanese Black and Holstein in POO-PPO relationships. Thcse relationships were similar to that of the intramuscular triacylglycerol ${ }^{5)}$. The concentrations of $\mathrm{POO}$ and $\mathrm{POL}$, and $\mathrm{POO}$ and $\mathrm{PPO}$ in triacylglycerol may affect reciprocally at synthetic stages of triacylglycerol molecule for depot fat.

The coefficients of the pattern similarity ${ }^{12.14)}$, showing total similarities of fatty acid and molecular species compositions of triacylglycerol, are shown in Table 3. The coefficient between Japanese Black and Japanese Shorthorn was larger than that between Japanese Black and Holstein. These relationships show that fatty acid and molecular species compositions between Japanese Black and Japanese Shorthorn were closer than that between Japanese Black and Holstein on the whole.

Relation of molecular species composition of triacylglycerol and lipid content of $M$. longissimus thoracis or meat quality score of carcass

There were no relationships of the second order regression or the exponential regression between total lipid content of $M$. longissimus thoracis and any molecular species concentrations of subcutaneous triacylglycerol for the
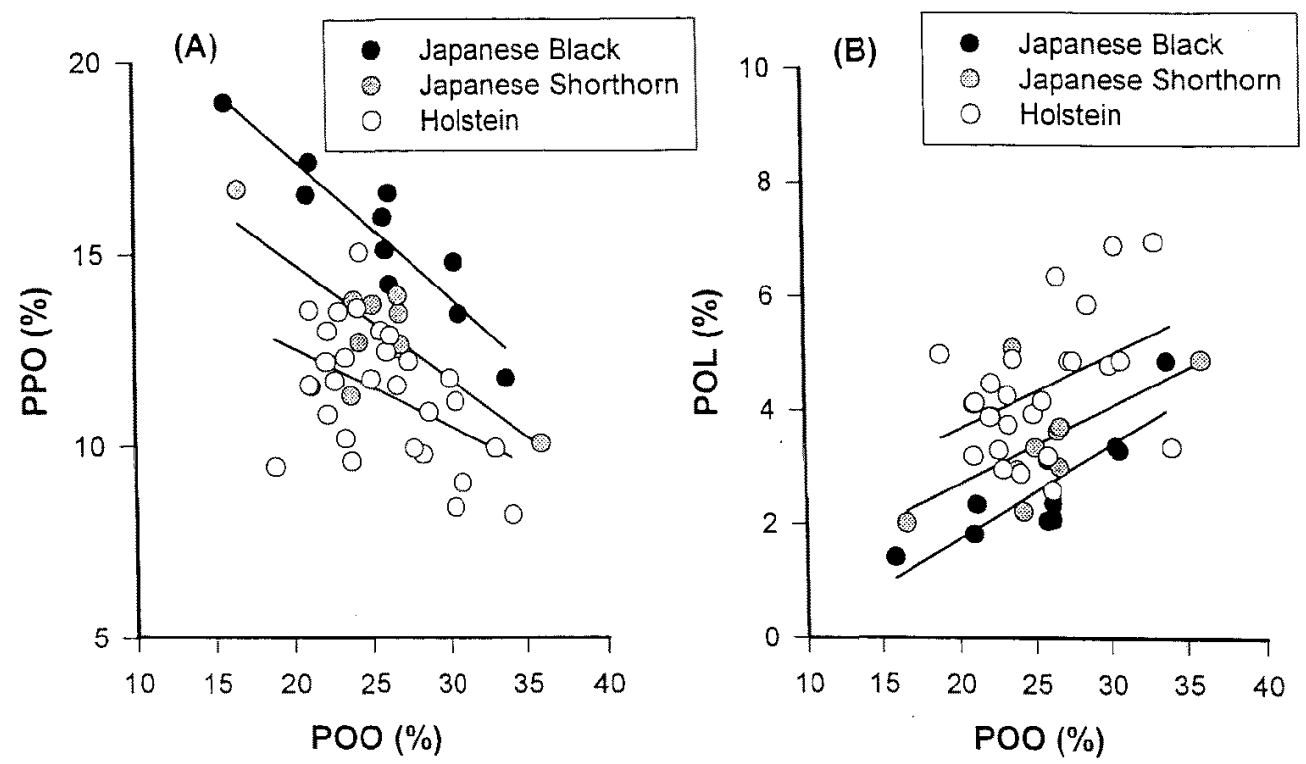

Fig. 2. Relationships between POO and PPO (A), and POO and POL (B) concentrations of the subcutaneous triacylglycerols of Japanese Black, Japanese Shorthorn and Holstein steers. 


\section{Molecular Species of Subcutaneous Triacylglycerols}

Table 3. Coefficienets of pattern similarities among three breeds based on the fatty acid composition and the molecular species composition of the subcutaneous triacylglycerol

(1) Pattern similarity based on the fatty acid composition

\begin{tabular}{lccc}
\hline & J. Black & J. Shorthorn & Holstein \\
\hline Japanese Black & 1.00000 & 0.99855 & 0.99084 \\
Japanese Shorthorn & 0.99855 & 1.00000 & 0.98950 \\
Holstein & 0.99084 & 0.98950 & 1.00000 \\
\hline
\end{tabular}

(2) Pattern similarity based on the molecular species composition

\begin{tabular}{lccc}
\hline & J. Black & J. Shorthorn & Holstein \\
\hline Japanese Black & 1.00000 & 0.99169 & 0.94713 \\
Japanese Shorthorn & 0.99169 & 1.00000 & 0.97891 \\
Holstein & 0.94713 & 0.97891 & 1.00000 \\
\hline
\end{tabular}

three breeds. Therefore, in order to analyze the relation of molecular species composition of subcutaneous triacylglycerol and total lipid content of $M$. longissimus thoracis, multiple regression analysis were carried out ${ }^{4)}$. In multiple regression analysis, using total lipid concentrations of $M$. longissimus thoracis for the dependent variable ( $y$ ) and molecular species concentrations of triacylglycerol for the independent variable, the linear multiple regression equation $\mathrm{y}=-2.13(\mathrm{PPO})+7.07(\mathrm{PHL})+52.43$ was obtained for Japanese Black. This regression equation with significant $\mathrm{F}$ value $(\mathrm{P}<0.05)$ had good multiple correlation coefficient (0.8110) and coefficient of determination (0.6578). The regression equations $y=0.22$ $(\mathrm{POO})+5.50$ for Japanese Shorthorn, and $\mathrm{y}=-$ $0.86(\mathrm{PPO})+27.94$ for Holstein had low multiple correlation coefficients of 0.4635 for Japanesc Shorthorn and 0.2648 for Holstein. In these equations, there were no common independent variables selected for three breeds, while PPO was a common variable for Japanese Black and Holstein, Using combined data of Japanese Black, Japanese Shorthorn and Holstein, the regression equation had low multiple correlation coefficient of 0.4691 . In multiple regression analysis, using molecular species concen- trations of intramuscular triacylglycerol in $M$. longissimus thoracis ${ }^{5)}$ for the independent variable, the regression equations of Japanese Black and Japanese Shorthorn had high multiple correlation coefficients of 0.9504 and 0.9625 respectively, while the regression equation of Holstein had low coefficient of 0.2368 . From these results, molecular species compositions of subcutaneous triacylglycerol of Japanese Shorthorn and Holstein may have no close relationships with total lipid concentration of $M$. longissimus thoracis.

In order to analyze the relation of meat quality score of carcass and molecular species composition of subcutaneous triacylglycerol, stepwise linear discriminant analysis was carried out $^{4)}$. In the discriminant analysis, samples were separated into two groups according to meat quality score of grading for carcass. Two groups for Japanese Black were $G 1$ for 3 ( 1 animal) +4 ( 3 animals) of meat quality score and $G 2$ for 5 ( 6 animals) of score. Two groups for Japanese Shorthorn and for Holstein were $G 1$ for 2 (5 animals) of meat quality score and $G$ 2 for 3 ( 5 animals) of score, and G1 for 2 (2 animals) +3 (15 animals) of score and $G 2$ for 4 (13 animals) of score, respectively. Results of the linear discriminant analysis are shown in 
Table 4. Percentages of discrimination using the best two discriminant functions were $100 \%$ of each group for Japanese Black and Japanese Shorthorn, and 82.4 to $84.6 \%$ for Holstein. For Japanese Black, [MPS], [PHO] and POL were included in the discriminant functions. For Japanese Shorthorn PoPoPo, MSS and [PPoO] were included. Holstein had two discriminant factors of $\mathrm{PPO}$ and [PPoO]. [PPoO] was a common factor for Japanese Shorthorn and

Table 4. Discriminant functions and the results of discrimination for Japanese Black, Japanese Shorthorn and Holstein steers using the stepwise linear discriminant analysis procedures

(1) Japanese Black

(a) Discriminant functions

$$
\begin{aligned}
& \mathrm{G} 1=11.7 \times([\mathrm{MPS}])+30.1 \times([\mathrm{PHO}])+22.8 \times(\mathrm{POL})-52.6 \\
& \mathrm{G} 2=14.5 \times([\mathrm{MPS}])+43.6 \times([\mathrm{PHO}])+30.2 \times(\mathrm{POL})-89.3
\end{aligned}
$$

(b) Result of discrimination

\begin{tabular}{ccccc}
\hline \hline Group & $\begin{array}{c}\text { No. of } \\
\text { animals }\end{array}$ & No. of animals classified & Percent \\
\cline { 3 - 5 } & 4 & $G 1$ & $G 2$ & \\
\hline correct \\
G2 & 6 & 4 & 0 & 100.0 \\
\hline
\end{tabular}

(G $1: 3$ and 4 of meat quality score, $G 2: 5$ of meat quality score)

(2) Japanese Shorthorn

(a) Discriminant functions

$$
\begin{aligned}
& \mathrm{G} 1=-54.7 \times([\mathrm{PoPOPo}])+50.6 \times(\mathrm{MSS})+75.1 \times([\mathrm{PPoO}])-353.7 \\
& \mathrm{G} 2=-48.8 \times([\mathrm{PoPoPo}])+44.5 \times(\mathrm{MSS})+66.3 \times([\mathrm{PPoO}])-272.6
\end{aligned}
$$

\begin{tabular}{|c|c|c|c|c|}
\hline \multirow{2}{*}{ Group } & \multirow{2}{*}{$\begin{array}{l}\text { No. of } \\
\text { animals }\end{array}$} & \multicolumn{2}{|c|}{ No. of animals classified } & \multirow{2}{*}{$\begin{array}{l}\text { Percen } \\
\text { correct }\end{array}$} \\
\hline & & G 1 & G 2 & \\
\hline G1 & 5 & 5 & 0 & 100.0 \\
\hline $\mathrm{G} 2$ & 5 & 0 & 5 & 100.0 \\
\hline
\end{tabular}

(b) Result of discrimination

(G1:2 of meat quality score, $G 2: 3$ of meat quality score)

(3) Holstein

\begin{tabular}{|c|c|c|c|c|}
\hline \multirow{2}{*}{ Group } & \multirow{2}{*}{$\begin{array}{l}\text { No. of } \\
\text { animals }\end{array}$} & \multicolumn{2}{|c|}{ No. of animals classified } & \multirow{2}{*}{$\begin{array}{l}\text { Percent } \\
\text { correct }\end{array}$} \\
\hline & & G1 & $\mathrm{G} 2$ & \\
\hline G 1 & 17 & 14 & 3 & 82.4 \\
\hline $\mathrm{G} 2$ & 13 & 2 & 11 & 84.6 \\
\hline
\end{tabular}

(a) Discriminant functions

$$
\begin{aligned}
& \mathrm{G} 1=4.8 \times(\mathrm{PPO})+4.6 \times([\mathrm{PPOO}])-57.9 \\
& \mathrm{G} 2=4.3 \times(\mathrm{PPO})+5.1 \times([\mathrm{PPOO}])-58.5
\end{aligned}
$$

(b) Result of discrimination

(G $1: 2$ and 3 of meat quality score, G2: 4 of meat quality score) 


\section{Molecular Species of Subcutaneous Triacylglycerols}

Holstein. In discriminant analyses using combined data of the three breeds, percentages of discrimination were not good in any cases of grouping for four groups $(2,3,4$ and 5 of meat quality score), three groups $(2+3,4$ and 5 , or 2 , 3 and $4+5$ of meat quality score ) or two groups ( 2 and $3+4+5,2+3$ and $4+5$, or $2+3+4$ and 5 of meat quality score). These results suggest that there were no common discriminant factors for the three breeds for discrimination based on meat quality score.

\section{References}

1) Casey NH, van Niekerk WA, Spreeth EB. Fatty acid composition of subcutaneous fat of sheep grazed on eight different pastures. Meat Sci., $23: 55-63.1988$.

2) Dryden FD, Marchello JA. Influence of total lipid and fatty acid composition upon the palatability of three bovine muscles. J. Anim. Sci., $31: 36-41.1970$.

3) Folch J, Lees M. Saloane-Staniey GH, A simple method for the isolation and purification of total lipids from animal tissues. J. Biol. Chem., 226: 497-509. 1957.

4) Itoh M, Arihara K, Kondo $Y$. Associations between meat quality evaluation on carcass grading and fatty acid composition in muscle lipid of fattening Holstein steers. Anim. Sci. Technol. (Jpn.), 65 : 368-375. 1994.

5) Itoh M, Arihara K, Kondo Y. Molecular spacies composition of intramuscular triacylglycerol of beef. Anim. Sci. Technol., 68: 756-759. 1997.

6) Leat WMF. Fatty acid composition of adipose tissue of Jersey cattle during growth and development. J. Agric. Sci. Camb., $85: 551-558$. 1975.

7) Leat WMF. Depot fatty acids of Aberdeen Angus and Friesian cattle reared on hay and barley diets. J. Agric. Sci. Camb., 89: 575-582. 1977.

8) May SG, Sturdivant CA, Lunt DK, Miller RK, Smith SB. Comparison of sensory characteristics and fatty acid composition between Wagyu crossbred and Angus steers. Meat Sci., $35: 289-298.1993$.

9) Miller GJ, Masor ML, Riley ML. Intramuscular lipids and triglyceride structures in range and feedlot steers. J. Food Sci., $46: 1333-1335.1981$.

10) Ozutsumi $K$, Kawanishi $T$, Yamazaki $T$. Fatty acid composition in various depot fats of fattened Japanese Black and Holstein steers. Jpn. J. Zootech. Sci., 54 : 470-475. 1983.

11) Roberts WK. Effect of diet, degree of fatness, and sex upon fatty acid composition of cattle tissues. Can. J. Anim. Sci., 46 : 181-190. 1966.

12) Suyama $K$, Adachi $S$, Tsuchida J, Kamata $Y$, Dambara H. Fatty acid composition and molecular distribution of triglyceride isolated from depot fats of Japanese Short Horn steers. Jpn. J. Zootech. Sci., $55: 747-754.1984$.

13) Suyama K, Yamaji A, Kutida K, Adachi S, Mizuma Y. Fatty acid composition and Molecular distribution of triacylglycerol isolated depot fat of crossbred steers of Brahman Sire $\mathrm{x}$ Japanese Black, Japanese Shorthorn and Holstein dams. Jpn. J. Zootech. Sci., 61 : 1077-1083. 1990.

14) Tamura S, Osawa F . Amino acid pattern similarity between foods in Japan (Jpn). J. Jpn. Soc. Food and Nutrition, $22: 494-496.1969$.

15) Tsuneishi $E$, Watanabe A, Takimoto $Y$. The relation between fatty acid composition and molecular distribution of triacylglycerol isolated from depot fats in beef cattle. Anim. Sci. Technol. (Jpn.), 65 : 128-134. 1994.

16) Waldman RC, Suess GG, Brungardt V. Fatty acids of certain bovine tissues and their association with growth, carcass and palatability traits. Anim. Sci., $27: 632-635.1968$.

17) Watanabe K, Sato Y. Meat Flavor. Jpn. J. Zootech., 45 : 113-128. 1974.

18) Wesserman AE, Talley F. Organoleptic identification of roasted beef, veel, lamb and pork as affected by fat. J. Food Sci., $33: 219-223.1967$.

19) Westerling DB, Hedrick HB. Fatty acid compo. sition of bovine lipids as influenced by sex and anatomical location and relationship to sensory characteristics. J. Anim. Sci., 48: 1343-1348. 1979.

20) Yoshimura T, Namikawa K. Influence of breed, sex and anatomical location on lipid and fatty acid composition of bovine intermuscular fat. Jpn. J. Zootech. Sci., $56:$ 122-129. 1987.

21) Yoshimura T, Namikawa K. Influence of breed, sex and anatomical location on lipid and fatty acid composition of bovine body-cavity fat. Jpn. J. Zootech. Sci., 56 : 130-136. 1987.

22) Zembayashi $M$, Nishimura $K$, Lunt DK, Smith SB. Effect of breed type and sex on the fatty acid composition of subcutaneous and intramuscular lipids of finishing steers and heifers. J. Anim. Sci., $73:$ 3325-3332. 1995. 


\title{
肥育牛の皮下脂肪トリアシルグリセロールの分子種組成および その胸最長筋全脂質含量との関連性
}

\author{
伊藤 良・有原圭三・近藤 洋 \\ 北里大学獣医畜産学部, 十和田市 034
}

肥育された黒毛和種，日本短角種㧍よびホルスタイン種の皮下脂肪のトリアンルグリセロールの脂肪 酸組成执よび分子種組成をガスクロマトグラフィーによって測定した．いずれかの二品種間には 7 つの 脂肪酸 (ミリスチン酸, 、ミリストレン酸, パルミチン酸, パルミトレイン産, anteiso-ヘプタデカン酸, へプタデカン酸およびステアリン酸)の濃度に差が認められた。パルミチン酸とオレイン酸の浸度間に は負の関係があった. 皮下脂肪のトリアシルグリセロールの主要分子種は, ミリストイル(M)-パルミ トイル (P)-オレオイル (O)-グリセロール (MPO), PPO, P-バルミトレオイル (Po)-O-グリセロール

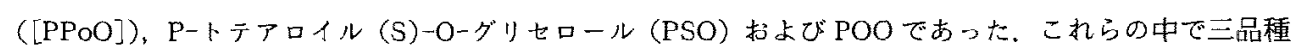
ともPOOが最も多かった，黒毛和種ではPSO お上び SOLの含量がホルスタイン種より多かった. POL とPOO 濃度閒には正, PPO 上POO間には負の関係肪あった。胸最長筋の全脂肪含量と分子種組 成との関連性を解析するために重回帰分析を行ったところ，黒毛和種の重回帰式が良好な重相関係数を 持っていた，試料を採取した枝肉の肉質等級を二群に分類して行った判別分析では，黒毛和種および日 本短角種で二群とも $100 \%$ の正判別率であっだ.

日畜会報，68 (12)：1118-1126，1997 